\title{
The Importance of Alpha-Actinin Proteins in Platelet Formation and Function, and Their Causative Role in Congenital Macrothrombocytopenia
}

\author{
Leanne R. O'Sullivan ${ }^{1}$, Mary R. Cahill ${ }^{2}\left(\mathbb{D}\right.$ and Paul W. Young ${ }^{1, *}$ (i) \\ 1 School of Biochemistry \& Cell Biology, University College Cork, T12 XF62 Cork, Ireland; \\ 1.r.osullivan@umail.ucc.ie \\ 2 Department of Haematology and CancerResearch@UCC, Cork University Hospital, University College Cork, \\ T12 XF62 Cork, Ireland; MaryR.Cahill@hse.ie \\ * Correspondence: p.young@ucc.ie
}

Citation: O'Sullivan, L.R.; Cahill, M.R.; Young, P.W. The Importance of Alpha-Actinin Proteins in Platelet Formation and Function, and Their Causative Role in Congenital Macrothrombocytopenia. Int. J. Mol. Sci. 2021, 22, 9363. https://doi.org/ $10.3390 /$ ijms 22179363

Academic Editor: Isabella Russo

Received: 11 August 2021

Accepted: 26 August 2021

Published: 29 August 2021

Publisher's Note: MDPI stays neutral with regard to jurisdictional claims in published maps and institutional affiliations.

Copyright: (c) 2021 by the authors. Licensee MDPI, Basel, Switzerland. This article is an open access article distributed under the terms and conditions of the Creative Commons Attribution (CC BY) license (https:// creativecommons.org/licenses/by/ $4.0 /)$.

\begin{abstract}
The actin cytoskeleton plays a central role in platelet formation and function. Alphaactinins (actinins) are actin filament crosslinking proteins that are prominently expressed in platelets and have been studied in relation to their role in platelet activation since the 1970s. However, within the past decade, several groups have described mutations in ACTN1/actinin-1 that cause congenital macrothrombocytopenia (CMTP) - accounting for approximately $5 \%$ of all cases of this condition. These findings are suggestive of potentially novel functions for actinins in platelet formation from megakaryocytes in the bone marrow and/or platelet maturation in circulation. Here, we review some recent insights into the well-known functions of actinins in platelet activation before considering possible roles for actinins in platelet formation that could explain their association with CMTP. We describe what is known about the consequences of CMTP-linked mutations on actinin- 1 function at a molecular and cellular level and speculate how these changes might lead to the alterations in platelet count and morphology observed in CMTP patients. Finally, we outline some unanswered questions in this area and how they might be addressed in future studies.
\end{abstract}

Keywords: actin cytoskeleton; actinin; actinin-1; actinin-4; ACTN1; platelets; congenital macrothrombocytopenia; macrothrombocytopenia; CMTP; megakaryocytes

\section{Introduction}

A normal platelet count and proper platelet function are essential for haemostasis. Disorders of platelet number of unknown cause are increasingly diagnosed in the haematology laboratory during routine blood counts [1], which may go without further investigation if not associated with bleeding [2], but these findings raise questions about genetic influences on platelet count. The actin cytoskeleton plays critical roles in platelet production by megakaryocytes in the bone marrow, their release into circulation and their function in terms of activation and aggregation in response to vascular damage. Cooperation between myosin motors and crosslinking proteins acting on actin filaments contribute significantly to the dramatic changes in cellular morphology that typify these processes [3]. Actinins are major actin crosslinking proteins in platelets that have recently been linked in genetic studies to abnormalities in platelet count and size [4] - joining other cytoskeletal proteins including myosins (MYH9), fimbrin (another prominent actin crosslinker) and tubulin subunits in this regard [5].

Our objective here is to review what is known about the roles of actinins in platelet generation and function, and outline potential cellular and molecular mechanisms that may underlie the platelet abnormalities associated with actinin-1 mutations. We will first describe the actinin gene family and the structure of actinin proteins before giving a brief perspective on their significance in platelet activation. Then, we will outline the key 
molecular interactions of actinins with integrins and other platelet proteins. Turning to the genetic variations within the actinin-1 gene that cause macrothrombocytopenia (CMTP), we will focus on the cellular and molecular consequences of these mutations and speculate regarding the stages in platelet formation and function that they may affect. Finally, we will outline some of the open questions that need to be addressed by future research in this area.

\section{Actinin Genes and Proteins}

Actinins are widely expressed, F-actin binding and crosslinking proteins that are part of the spectrin superfamily, which also contains spectrin, utrophin and dystrophin $[6,7]$. The domain structure of mammalian actinins consists of an amino-terminal actin-binding domain (ABD), a central rod domain and a carboxyl-terminal calmodulin-like (CaM) domain (Figure 1). Actinins function as antiparallel dimers, which allows them to crosslink actin filaments. Dimerization is largely mediated by the central rod domain which places the ABDs at either end of the molecule, spaced approximately $30 \mathrm{~nm}$ apart. The actinin dimer has significant elasticity and is curved axially and twisted, allowing it to resist mechanical forces and provide high-affinity binding sites for other proteins [8]. The CaM domain from one subunit can bind to a "neck" region between the ABD and rod of the other subunit in an actinin dimer $[9,10]$. This close proximity of the CaM and ABD domains from opposing subunits likely explains how $\mathrm{Ca}^{++}$binding to the $\mathrm{CaM}$ domain can inhibit the crosslinking of actin filaments in some, $\mathrm{Ca}^{++}$-sensitive, actinin isoforms [11] (Figure 1).
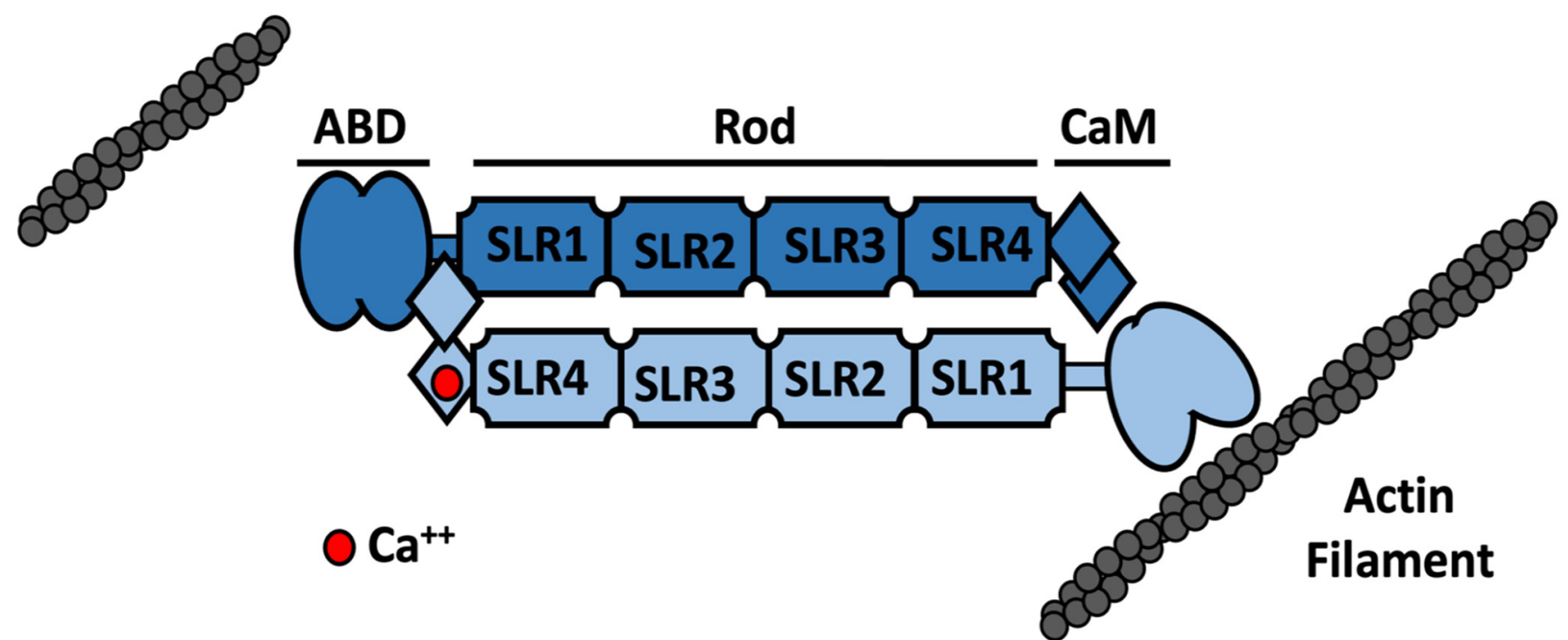

Figure 1. Schematic representation of the structure of the actinin dimer and its regulation by calcium. Actinins are $\sim 100 \mathrm{kDa}$ proteins that form dimers that are $\sim 36 \mathrm{~nm}$ long and $\sim 6 \mathrm{~nm}$ wide [9]. Each monomer comprises an amino-terminal actin binding domain (ABD) that is made up of two tandem calponin homology $(\mathrm{CH} 1-\mathrm{CH} 2)$ domains. These $\mathrm{CH}$ domains rearrange from a closed conformation in the absence of actin to a more open, higher affinity state when bound to actin [6,12]. The rod domain facilitates the antiparallel dimerization of actinin and consists of four sprectrin-like repeats (SLRs) with a three-helix bundle structure and high sequence homology to those found in spectrin and dystrophin [6,12]. The carboxylterminal calmodulin-like (CaM) domain comprises four helix-loop-helix EF-hand motifs (EF1-4) [7]. EF 3-4 interacts with the neck region between the $\mathrm{ABD}$ and first spectrin repeat of the other actinin subunit $[9,10]$. In $\mathrm{Ca}^{++}$-sensitive actinin isoforms, $\mathrm{EF} 1$ can bind a single $\mathrm{Ca}^{++}$ion and the solution structure of the actinin-1 CaM domain suggests that while EF3-4 binds to the neck region in the presence of $\mathrm{Ca}^{++}$, it is not associated or only loosely associated with the neck region when $\mathrm{Ca}^{++}$is not bound to EF1 [11]. A conformational change involving opening of EF hand 1-2 and structural stabilisation of the domain occurs when bound to $\mathrm{Ca}^{++}$which also reduces the flexibility of the adjacent ABD and inhibits actin binding [11]. The $\mathrm{Ca}^{++}$-bound, inhibited state and $\mathrm{Ca}^{++}$-free, $\mathrm{F}$-actin-bound states are shown here on the left and right hand sides of a single actinin dimer for illustrative purposes only.

There are four genes coding for actinins: ACTN1-4. Actinin-2 and actinin-3 are $\mathrm{Ca}^{++}-$ insensitive proteins, predominantly expressed in muscle, with some expression of actinin-2 
in the brain. By contrast, actinin- 1 and actinin- 4 can exist as $\mathrm{Ca}^{++}$-sensitive or -insensitive isoforms. These isoforms arise due to alternative splicing of two variants of an exon which encodes part of the first EF-hand motif of the CaM domain. $\mathrm{Ca}^{++}$-sensitive variants of actinin- 1 and actinin- 4 are expressed broadly in many tissues [13]. However, the expression of $\mathrm{Ca}^{++}$-insensitive variants is somewhat more specific, with $\mathrm{Ca}^{++}$-insensitive actinin-1 being expressed in muscle, smooth muscle and some other tissues, while $\mathrm{Ca}^{++}$-insensitive actinin-4 was found only in the brain and spinal cord [13].

Platelet actinin was shown to be $\mathrm{Ca}^{++}$-sensitive [14] and had probably been assumed in most studies to be the $\mathrm{Ca}^{++}$-sensitive, non-muscle isoform of actinin-1. Indeed, the expression of this isoform in platelets was confirmed by cDNA sequencing [15]. However, quantitative proteomics indicates the presence of both actinin- 4 and actinin- 2 in addition to actinin- 1 in platelets, with $\sim 92,000, \sim 45,000$ and $\sim 25,000$ copies per platelet estimated for actinin-1, -4 and -2 , respectively [16]. We have also detected these three isoforms in platelet lysates by Western blotting with isoform-specific antibodies [13]. Thus, while $\mathrm{Ca}^{++}$-sensitive actinin-1 is likely the most abundant platelet actinin isoform, the potential roles of actinin- 4 and actinin- 2 have not received as much attention as they deserve.

\section{Actinin in Platelet Activation and Adhesion}

Platelet size and shape change are essential components of platelet activation and have been much studied in both the research laboratory and clinical setting. In resting platelets, the actin cytoskeleton resembles spokes of a wheel, with F-actin radiating from the membrane to cell centre and a dense spectrin-rich shell encases the actin core [3]. At the cell centre is a microtubule circumferential band. During activation, cells transition from a discoid to a spherical shape [17]. Actin filaments are severed in this process and then polymerised to form filopodia [17]. Granules are centralised in the platelet during this process [17]. The contraction of the microtubule coil occurs by the action of actin and the myosin IIA which connects microtubules to actin [3]. This fundamental shape change, and the mechanisms that underlie it, are of huge importance clinically [18]. As platelets become activated and undergo shape change, their surface area increases and the available surface for interaction of GPIb/IX and GPIb-IX-V with other platelets and the endothelium is maximised [19]. Hence, the actin cytoskeleton and associated cytoskeletal proteins have key roles in platelet activation.

The involvement of actinin in platelet activation was apparent from early studies describing actinin as an abundant $\sim 100 \mathrm{kDa}$ protein component of the platelet cytoskeleton that is involved in the bundling of actin microfilaments within pseudopods of activated platelets [20-22]. Platelet actinin was shown to bundle actin filaments in a $\mathrm{Ca}^{++}$-sensitive manner [14], though the potential presence of multiple actinin isoforms in platelets with subtle differences in their $\mathrm{Ca}^{++}$sensitivity was apparent [23]. In the absence of complete amino acid sequences for the various actinins, these studies employed the nomenclature a, $\mathrm{b}$, c based on molecular mass [23]. Two isoforms, dimers aa $(2 \times 97 \mathrm{kD})$ and cc $(2 \times 94 \mathrm{kD})$, were described as being $\mathrm{Ca}^{++}$-sensitive actin-binding and crosslinking proteins, although aa was shown to be more strongly inhibited by $\mathrm{Ca}^{++}$than cc [23]. Additionally, the actin crosslinking efficiency was higher in cc than aa [23]. How these isoforms correspond to subsequently identified actinin- 1 and actinin- 4 variants and or post translationally modified versions of these is not clear.

Receptor-mediated activation of platelets with ADP, thrombin or fibrinogen was shown to cause increased association of actinin with the platelet cytoskeleton [24-26] and actinin, along with filamin (actin binding protein/ABP), and myosin were proposed to play important roles in the dramatic changes in cell shape associated with platelet activation. The association of actinin with platelet secretory vesicle membranes [27] and its potential to directly interact with membranes containing diacylglycerol in activated platelets [28] were recognized early on, and supported the potential roles of actinin and vinculin [29] in anchoring actin filaments to membranes. 
In surface-activated spread platelets, actinin was localised at punctuate structures and co-localised with actin filaments, in the cytoplasm, at the filopodia edges, on the cell membrane and around the granulomere [30]. Actinin localised with myosin at the cell membrane, in the cytoplasm and near the granulomere and vinculin was also concentrated at punctate structures near the plasma membrane, possibly associated with actinin at sites of adhesion [30]. Actinin has also been localised to structures called actin nodules, which form during early adhesion and spreading of platelets [29,30]. Platelet actin nodules consist of one to four dense F-actin foci which are interconnected by actin fibres and enhance platelet aggregate stability under flow [31].

\section{Molecular Interactions of Actinin in Platelets}

\subsection{Integrins}

The major platelet integrin $\alpha \mathrm{IIb} \beta 3$ plays a significant role in platelet aggregation. There are $80-100,000$ copies of integrin $\alpha \mathrm{Ilb} \beta 3$ on platelet plasma membrane and also in alpha granules [32]. A key insight with regard to actinin function in platelets came with the identification of interactions between actinin and integrins via $\beta 1$ and $\beta 3$ subunits, and the demonstration of actinin binding to platelet $\alpha \mathrm{Ilb} \beta 3$ integrin [33]. This interaction suggested a potential direct linkage between cell surface integrins and actinin bound to actin filament compared to more indirect mechanisms involving vinculin and talin.

Regulatory mechanisms that might modulate such integrin:actin linkages via actinin subsequently emerged. For example, it was demonstrated that tyrosine phosphorylation of actinin-1 occurs in phorbol 12-myristate 13-acetate activated platelets and that this phosphorylation also occurs in platelets spreading on fibrinogen and is dependent on $\alpha \mathrm{IIb} \beta 3$. The kinase responsible for this phosphorylation was identified as focal adhesion kinase (FAK) and the phosphorylation of actinin-1 at tyrosine 12 by FAK was shown to inhibit its binding to actin filaments [15]. Actinin can be dephosphorylated by SHP-1 phosphatase, which occurs in resting and thrombin stimulated platelets [34]. However, in fibrinogen adherent platelets, inactivation of SHP-1 leads to an increase in actinin phosphorylation [34]. In thrombin stimulated platelets, the dephosphorylation of actinin may strengthen its association with integrins and the cytoskeleton, aiding aggregates to resist shear forces [34]. In contrast, fibrinogen activation causes sustained actinin phosphorylation and reduced association with actin, promoting a dynamic network that favours cell movement and reorganisation of actin filaments [34]. These studies indicate potential reciprocal regulation of actinin phosphorylation by FAK and SHP-1 in platelets.

In addition, regulation of actinin by phosphoinositides is likely to be relevant in platelets. Phosphatidylinositol $(3,4,5)$-trisphosphate $\left(\mathrm{PIP}_{3}\right)$, produced by activated phosphatidylinositol 3-kinase (PI3K), reduces actinin affinity for $\beta$ integrins and its ability to bundle F-actin, promoting cell detachment at focal adhesions in migrating cells $[33,34]$. $\mathrm{PIP}_{2}$ and $\mathrm{PIP}_{3}$ also regulate proteolysis of actinin by calpains, with $\mathrm{PIP}_{2}$ decreasing and $\mathrm{PIP}_{3}$ increasing cleavage [35]. $\mathrm{PIP}_{3}$ increases cleavage by increasing the flexibility of the neck region connecting the ABD and SLR1 of the rod domain, while $\mathrm{PIP}_{2}$ stabilises this structure to reduce cleavage [36]. $\mathrm{PIP}_{2}$ and $\mathrm{PIP}_{3}$ are thus involved in regulating actinin turnover in the cell which controls remodelling of the actin cytoskeleton [37].

Subsequent to inside-out signalling, integrin $\alpha \mathrm{IIb} \beta 3$ transitions from a low-affinity state and activated integrin molecules are exposed on the platelet surface [3]. Talin and kindlin binding to the cytoplasmic tail of the integrin induce the conformational shift to the high-affinity state, enabling binding of fibrinogen and VWF $[1,25]$. Further work into the role of actinin in this process has shown that actinin associates with $\beta 3$ in the resting state in platelets but becomes dephosphorylated and dissociates in response to inside-out signalling from protease activated receptors, with long-lasting activation of $\alpha \mathrm{Ilb} \beta 3$ in response to PAR4 stimulation [38]. Actinin and talin were shown to bind competitively to $\beta 3$ integrin in fibroblasts adhering to fibronectin, with talin involved in initial adhesion and actinin replacing talin to facilitate adhesion maturation [39]. The expression of the integrin binding domain only in actinin depleted cells reduced force generation on fibronectin, highlighting 
that actinin also elicits some effect independent of actin interaction [39]. The mechanisms behind this have been assessed using molecular dynamics simulations [40]. The binding of actinin to $\beta 3$ was shown to cause a proline-induced kink in the $\beta 3$ transmembrane domain, which impairs integrin activation [40]. It also prevents talin binding to $\beta 3$, possibly by interacting with both proteins simultaneously [40]. These results are consistent with actinin having a role in setting $\alpha \operatorname{Ilb} \beta 3$ to a low-affinity state, with inside-out signalling causing its dephosphorylation and dissociation, facilitating talin binding and activation of $\alpha \mathrm{IIb} \beta 3$ [38].

$\beta 1$ integrin also interacts directly with actinin via its cytoplasmic domain [33]. The $\beta 1$ integrin subunit is found in various platelet receptors, including the fibronectin, laminin and collagen receptors [33]. Notably, talin and actinin bind cooperatively to the $\beta 1$ integrin cytoplasmic [39] and so the role of actinin in relation to $\beta 1$ subunit-containing platelet integrins may be different from that for $\alpha \mathrm{Ilb} \beta 3$ [40]. Shams and Mofrad (2017) found that actinin restricts the motion of the $\beta 1$ cytoplasmic tail, supporting talin association [40]. This regulation of integrins could modify mechanical signal transmission in the processes of adhesion and cell spreading [40].

\subsection{GPIb-IX-V}

Platelet adhesion to the vascular endothelium is an important component of haemostasis and is facilitated mainly by platelet adherence to exposed VWF and collagen via the GPIb-IX-V complex [32]. The GPIb-IX-V complex also interacts with $\alpha \mathrm{M} \beta 2$ (Mac-1) on leucocytes [41]. The importance of the GPIb-IX-V complex is underscored by the bleeding phenotype exhibited by patients with inherited defects in GPIb - the rare Bernard Soulier syndrome [42]. The VWF-GPIb-IX interaction is a stimulus for platelet aggregation and eventual activation of integrin $\alpha \mathrm{IIb} \beta 3$ [43]. Actinin and the GPIb-IX complex were coimmunoprecipitated in response to exposure to shear stress, and this was dependent on VWF binding to GPIb $\alpha$ and actinin becoming phosphorylated [44]. Shear stress and the subsequent phosphorylation also enhanced PKN binding to actinin, speculated to indicate a role for actinin in the formation of a signalling complex with GPIb-IX in response to shear and VWF [44]. In resting platelets, non-phosphorylated actinin associates with PI3K, protein kinase $\mathrm{N}(\mathrm{PKN})$ and $\mathrm{PIP}_{2}[43,44]$. Shear stress induced the dissociation of actinin and $\mathrm{PIP}_{2}$ from PI3K and the production of $\mathrm{PIP}_{3}$ [43]. This complex reassembles at GPIb, with actinin linking the receptor to the cytoskeleton and a second phase of $\mathrm{PIP}_{3}$ production occurs that is speculated to maintain GPIb in an activated state and stabilise the nascent thrombus [43].

\subsection{CLP36}

CLP36 associates with actin filaments in activated platelets via actinin-1 [45]. CLP36 binds to actinin-1 via SLR2 and SLR3 of the rod domain in both resting and activated platelets [45]. The complexed proteins are not localised to focal adhesions, speculated to be due to a regulatory role of CLP36 [45]. This was thought to involve the promotion of actininactin interactions at stress fibres through the inhibition of actinin-integrin interactions at focal adhesions, mediated by CLP36 binding [45]. Actinin, non-filamentous actin, CLP36 and plasma membrane calcium ATPase (PMCA) are found in a complex in resting and activated platelets [46]. This demonstrates a potential role for actinin in localising proteins to platelet structures such as filopodia in activated platelets [45].

\subsection{Regulation of Actinin Molecular Interactions}

Phosphorylation of actinin- 1 and the regulation of actinin- 1 by phosphoinositides and calcium have been mentioned above. Similar regulatory mechanisms have been described for actinin-4, though not in the context of platelets, outlined in Table 1. For example, tyrosine phosphorylation of actinin- 4 has also been demonstrated, with phosphorylation at Tyr4 and Tyr31 inhibiting actin binding, whereas phosphorylation at Tyr265 appeared to enhance actin binding as well as calpain cleavage of actinin-4 [47]. Phosphorylation of Tyr4 and Tyr31 was shown to maintain the ABD in a closed conformation, inhibiting actin 
binding [48]. Tyr4 phosphorylation acts as a switch which regulates phosphorylation of Tyr31, and is absent in calpain cleaved actinin [49]. Tyrosine phosphorylation at different residues (Tyr11 and Tyr13) required FAK and had minimal effects on actin binding while inhibiting calpain cleavage of actinin-4 [50]. Binding of phosphoinositides $\mathrm{PIP}_{2}$ and $\mathrm{PIP}_{3}$ could also inhibit cleavage of actinin-4 by m-calpain [51]. Thus, similarly to actinin-1, phosphorylation and phosphoinositide binding can modulate actin binding and protease susceptibility of actinin-4. The significance of these regulatory mechanisms in platelets remains unclear, however.

Table 1. Regulation of non-muscle actinins by tyrosine phosphorylation.

\begin{tabular}{|c|c|c|c|}
\hline Isoform & Site & $\begin{array}{c}\text { Effect of } \\
\text { Phosphorylation }\end{array}$ & Reference \\
\hline Actinin-1 & Tyr 12 & $\begin{array}{ll}\text { - } & \text { Reduced actin } \\
\text { binding } \\
\text { - } & \text { Enhanced cell } \\
\text { mobility } \\
\text { - } & \text { Enhanced PKN } \\
\text { binding } \\
\text { - } & \text { Association with } \\
\text { B3 integrin }\end{array}$ & {$[15,38,44]$} \\
\hline \multirow{5}{*}{ Actinin-4 } & Tyr 4 & $\begin{array}{ll}\text { - } & \text { Inhibits actin } \\
\text { binding } \\
\text { - } & \text { Regulates Tyr } 13 \\
\text { phosphoryla- } \\
\text { tion } \\
\text { - Absent in } \\
\text { calpain cleaved } \\
\text { actinin-4 }\end{array}$ & [47-49] \\
\hline & Tyr 11 & $\begin{array}{ll}\text { - } & \text { Slight decrease } \\
\text { in actin binding } \\
\text { - } \\
\text { Resistance to } \\
\text { calpain cleavage }\end{array}$ & [50] \\
\hline & Tyr13 & $\begin{array}{ll}\text { - } & \text { Slight decrease } \\
\text { in actin binding } \\
\text { - } \\
\text { Resistance to } \\
\text { calpain cleavage }\end{array}$ & [50] \\
\hline & Tyr 31 & $\begin{array}{l}\text { Inhibits actin } \\
\text { binding }\end{array}$ & {$[48,49]$} \\
\hline & Tyr 265 & $\begin{array}{ll}\text { - } & \text { Enhances actin } \\
\text { binding } \\
\text { Increases } \\
\text { calpain cleavage } \\
\text { of actinin- } 4\end{array}$ & [47] \\
\hline
\end{tabular}

As mentioned, calcium binding negatively regulates the interaction of actinin- 1 and actinin-4 with actin [52]. Calcium signalling is critical in platelet activation and assessing the impact of calcium concentration changes on the interaction of actinin with other cellular proteins in platelets is a topic that merits further study. In thrombin activated platelets, phosphorylated actinin has been reported to immunoprecipitate with transient receptor potential channels, possibly indicating a role in store operated calcium entry, which the authors note is similar to a reported role for muscle actinin in calcium channel regulation in cardiac myocytes [53]. Nitrous oxide (NO) may also regulate actinin-1 in platelets by a transient tyrosine nitration, which is thought to prevent its phosphorylation [54]. These authors propose that tyrosine nitration of actinin, through peroxynitrite formation, may be a modulatory mechanism that inhibits platelet adhesion. 


\section{Involvement of Actinin-1 in Platelet Formation}

Platelet formation from megakaryocytes can be considered as a number of sequential steps. While actinins have not been studied extensively in this context, there are several of these steps in which a role for actinin has been described or can be inferred based on our understanding of actinins in other cellular processes.

\subsection{Megakaryocyte Maturation}

Megakaryocytes mature by undergoing endomitosis to increase ploidy [55]. This process is thought be important to generate large quantities of RNA and granule contents for platelets [56]. This occurs through a failure of cytokinesis and involves F-actin, myosin IIA and RhoA [55]. RhoA knockdown caused increased MK ploidy, aberrant proplatelet release and macrothrombocytopenia [55]. Additionally, downregulation of the myosin II heavy chain MYH10 by RUNX1 regulates the failure of cytokinesis during endomitosis through a defect in the actin-myosin II contractile ring [55]. Actinin is known to play a central role in the formation of the contractile ring during cytokinesis in other contexts, working in concert with myosin II (reviewed in [52]). Overexpression of actinin causes a failure in cytokinesis and thus polyploidization [57]. Actinin-1 was shown to be upregulated during megakaryopoiesis and knockdown of actinin-1 in megakaryocytes prevented polyploidisation and cell enlargement, while also causing filamin A levels to be diminished $[58,59]$. These observations suggest that actinin expression levels and potentially its actin filament crosslinking activity may influence the process of endomitosis during megakaryocyte maturation.

\subsection{Proplatelet Formation and Platelet Release}

Maturing megakaryocytes move from the haematopoietic niche to the vascular niche within the bone marrow and, at the vascular niche, extend cytoplasmic protrusions called proplatelets through the vessel endothelium into the bloodstream [55]. Platelets are then released from the proplatelet in the bloodstream. Microtubules are the major cytoskeletal components of proplatelets, lining the proplatelet shaft with microtubule sliding, driven by the motor protein dynein, making a major contribution to the proplatelet extension process $[60,61]$. The microtubules loop back into the shaft at the end of each process, forming a platelet-sized tip [60]. Microtubules and their motor proteins, kinesins, also facilitate the delivery of granules and organelles to the platelets, at proplatelet tips [55].

However, the actomyosin network is also important for proplatelet formation. Platelets are formed only at the ends of proplatelets, and actin promotes branching of the proplatelets, yielding a greater number of tips [62]. Although actin has a role in increasing tip number on the proplatelets, actin disruption accelerates proplatelet extension [55]. Regulators of actin polymerisation also play a role in platelet formation, with RhoA, Pak2 and mDia1 affecting proplatelet formation [55]. Myosin IIA mutations also decrease the number of proplatelets formed [55]. While the role of actinins in proplatelet formation and extension has not been studied explicitly, they are likely to be involved on the basis of the many other dynamic cellular contexts in which myosin II motors and actinin crosslinking proteins work together. Additionally, megakaryocytes expressing actinin-1 with CMTP-causing actinin-1 mutations exhibited a reduced number of proplatelet tips and increased tip size, suggesting a role for actinin-1 in regulating this process [63].

As discussed previously, actinin has a role in setting $\alpha \mathrm{IIb} \beta 3$ to a low-affinity state. The constitutively activated integrin has previously been linked to abnormal proplatelet-like formation in cultured BHK cells [64]. Dysregulated integrin activation is a feature of a number of inherited macrothrombocytopenias. In subtypes of Glanzmann thrombasthaenia, mutations in $\alpha \mathrm{Ilb}$ and $\beta 3$ cause constitutive activation of the $\alpha \mathrm{IIb} \beta 3$ and cause macrothrombocytopenia [64,65]. Increased RhoA signaling through defective filamin $A$ and $\alpha \operatorname{Ilb} \beta 3$ interaction also underlies FLNA-linked macrothrombocytopenia [66]. Potentially, actinin also has a role in proplatelet formation through its interaction with $\alpha \operatorname{Ilb} \beta 3$. 
Podosomes are actin-rich structures that have been implicated in platelet formation, whereby podosome clusters connected by the actomyosin network enable the passage of proplatelets through the endothelial barrier during thrombopoiesis [67]. Although similar to platelet actin nodules, they differ as podosomes are larger and require WASp and Arp 2/3 for their formation [31]. They use matrix metalloproteases to degrade the basement membrane and thereby facilitate the release of platelets into the bloodstream [68]. Podosome structure has been best characterised in dendritic cells and macrophages and is comprised of an actin core, associated with protrusion, and an outer ring made up of proteins including vinculin and talin, associated with adhesion $[69,70]$. The core consists of actin and actin binding proteins, WASP, Arp 2/3, cortactin (predominantly associated with branched actin filaments, at the core centre) and actinin (associated with linear actin filaments at the core periphery) [71]. The core and ring are connected via an actomyosin network and cores on adjacent podosomes are connected via radial actin filaments [70]. Tension generated by the F-actin core and radiating actin network regulates the protrusive and adhesive activity of the podosome clusters [70].

Wiskott Aldrich syndrome is an X-linked disorder associated with immunodeficiency and thrombocytopenia involving a congenital mutation in the WAS protein (WASP) [72]. WASP is a component of podosomes and a regulator of actin polymerisation, and mutations are associated with premature platelet release into the bone marrow and microthrombocytopenia [73]. Recent studies have also examined mice with megakaryocyte-specific deficiencies in other proteins linked to podosome formation and function. Loss of Arp2/3 impaired the formation of transendothelial pores and the production of cytoplasmic processes, while loss of MHCIIA affected podosome size, distribution and number and caused scattered transendothelial pores [67]. Deficiencies in actin regulatory proteins twinfilin and cofilin were associated with macrothrombocytopenia, increased MK numbers in the bone marrow and spleen and reduced podosome formation [74]. These studies highlight the potential importance of podosomes for proper platelet production and release from megakaryocytes. Actinin is a key component of podosomes in dendritic cells [71] and we have detected both actinin- 1 and actinin- 4 in the podosomes of cultured murine megakaryocytes (LOS and PY, unpublished observations). Podosome-mediated protrusion of proplatelets into blood vessels may therefore represent a process in which actinins play a critical role during platelet production in vivo.

\subsection{Proplatelet Fission}

When the proplatelet tips are released into the blood, they may take the form of premature platelets, including preplatelets $(2-10 \mu \mathrm{m}$ ) or barbell shaped platelets (two $2 \mu \mathrm{m}$ platelets which are connected via a microtubule coil) $[75,76]$. These mature into discoid $2 \mu \mathrm{m}$ platelets, driven by shear forces during blood flow [55] or at sites such as the lung microvasculature [56]. A role for myosin II in this process has been described whereby shear forces activate myosin II, which then drives cleavage furrow formation and fission, resulting in the generation of normal small platelets [77]. These authors propose that macrothrombocytopenia in MYH9-related diseases arises because myosin II heavy chain mutations abrogate normal myosin activity, preventing cleavage furrow formation and platelet fission. Actinins are responsive to shear stress in platelets $[43,44]$ and implicated in mechanosensory signal transduction in other contexts [78-80]. The disease-associated actinin-4 mutant K255E has increased affinity for F-actin and was shown to be insensitive to mechanoregulation [81]. Whether actinin-1 mechanosensing is involved in proplatelet fission remains to be assessed. Actinins are likely to crosslink actin filaments in cleavage furrows formed during proplatelet fission in circulating blood and may be regulated by shear stress. Disruption of such a role could represent a mechanism underlying the macrothrombocytopenia associated with mutations in actinin-1. 


\section{Genetic Studies Linking Actinin-1 to Platelet Production}

Mutations in all four actinin genes have been described [82]. Mutations in ACTN2 and ACTN3 cause cardiomyopathies and alterations in muscle physiology, respectively, in line with their expression patterns. By contrast, despite their broad and overlapping expression patterns, ACTN1 and ACTN4 mutations are associated with diseases affecting a very specific physiological process. ACTN4 mutations cause the kidney disease focal segmental glomerulosclerosis [83] and actinin-4 seems to play a role in renal podocytes that cannot be compensated for by actinin-1 [84]. Most recently, ACTN1 mutations that cause a mild, non-syndromic, form of CMTP have been identified (Online Mendelian Inheritance in Man (OMIM) database link: https:/ / www.omim.org/entry/102575, accessed on 25 August 2021). These mutations as well as other genetic evidence linking actinin-1 to platelet production are discussed below.

\subsection{Discovery of CMTP-Causing Actinin-1 Mutations}

Genetic linkage studies in Japanese and French families led to the identification in 2013 of the first mutations in actinin-1 that cause CMTP $[63,85]$. Subsequently, these and additional novel mutations were identified in other patient cohorts. A review in 2017 catalogued 20 mutations [4] and more recent studies have brought the total number of different CMTP-causing actinin-1 mutations identified to approximately 40 [86-90]. With one exception (Luo 21; see below), these are all missense mutations that change a single amino acid within the actinin-1 protein, and all appear to be inherited in a dominant fashion. Mutations affecting all the functional domains of the protein (ABD, rod and CaM domain) have now been described [4]. Thrombocytopenia caused by actinin- 1 mutations is mild, with platelet counts of typically $50-130 \times 10^{9} / \mathrm{L}$ and the presence of enlarged platelets with a platelet diameter that has been reported to be $30 \%$ greater than controls $[4,63]$. Bleeding risk is generally low and no abnormalities beyond platelet count and size have been noted. More recently, it has been noted that some actinin-1 mutations, while causing macrocytosis, are not always associated with thrombocytopenia [86]. Rather than exhaustively cataloging these mutations and the clinical characteristics of affected patients, we will focus here on possible mechanisms by which the mutations could lead to platelet defects.

\subsection{Known Cellular and Molecular Consequences of CMTP-Linked Actinin-1 Mutation}

To explore how CMTP-linked actinin-1 mutations affect platelet production, Kunishima et al. (2013) expressed mutant actinin proteins in cultured murine megakaryocytes $[4,63]$. They reported a decrease in the number, but an increase in the size, of proplatelet tips for cells expressing actinin-1 mutants, with some differences in actin organization also noted. The proportion of megakaryocytes forming proplatelets was not altered, pointing toward a defect in the later stages of platelet production. Several groups have also reported that expression of actinin-1 with CMTP-linked mutations in cultured cells (fibroblasts, COS7, CHO cells) causes disorganization of the actin cytoskeleton or differences in the distribution of the mutant actinin-1 compared to the wild type protein $[63,85,86,91,92]$. By contrast, we did not see gross disruption of the actin cytoskeleton in HeLa cells expressing mutant actinin-1, though we did observe more stable association of mutant actinin-1 with the cytoskeleton $[93,94]$. These differences may be due to the cell lines used or the degree of overexpression of the mutant proteins.

To examine whether the mutations affect the actin binding and crosslinking activity of actinin-1, we also performed actin co-sedimentation assays. It was found that actinin1 with a mutation in the actin binding domain (R46Q) had a higher affinity for actin filaments, bundled actin filaments more efficiently and was more stably associated with actin filaments in cells compared to the wild type protein [93]. Other ABD mutations [93], as well as mutations within the rod and CaM domains [94], had similar effects on actin bundling. Mutations within the CaM domain did not dramatically alter $\mathrm{Ca}^{++}$binding but had variable effects on the stability of this domain, possibly explaining alterations in actin binding for these mutant proteins (Figure 1). Overall, these observations suggest a 
common molecular mechanism related to increased actin filament association for most, if not all, CMTP-linked actinin-1 mutations regardless of their location within the protein. Gain-of-function mutations of this type would explain a phenotype being observed in heterozygous individuals despite the presence of 50\% wild type actinin- 1 protein, as well as a significant amount of the highly similar actinin-4, and are consistent with the dominant inheritance pattern observed.

\subsection{Effects of Actinin-1 Expression Levels on Platelet Production}

Aside from missense mutations, a couple of genome-wide association studies (GWASs) have linked the ACTN1 gene to altered platelet parameters, possibly as a result of alterations in actinin-1 expression levels rather than affecting its coding sequence. Schick et al. (2016) performed a GWAS for platelet count in a cohort of Hispanic/Latino individuals in the USA and identified the strongest association with a variant (rs117672662) located within a putative megakaryocyte-specific enhancer region in an intron of the ACTN1 gene [95]. The variant allele showed increased transcriptional activity, but levels of actinin-1 protein were not examined. In an another GWAS for variation in blood cell parameters, two variants that linked ACTN1 to platelet parameters were identified [96]. In this study, the same rare variant mentioned above (rs117672662) was linked to alteration in mean platelet volume and platelet distribution width, while a different, more common variant was associated with mean platelet volume, albeit with a smaller effect size. Finally, a case of ACTN1-linked CMTP involving a frameshift mutation in ACTN1 has recently been reported [90]. This mutation is expected to cause production of a severely truncated protein and decreased levels of intact actinin- 1 were reported. This suggests that decreased levels of actinin-1 protein can give rise to a similar platelet phenotype as seen in patients with missense mutations.

\section{Unanswered Questions and Future Directions}

Despite the considerable literature on the topic outlined above, many questions remain regarding the functions of actinins in platelets and platelet production. One neglected area has been the role of actinins other than actinin-1. Actinin-4 is also present in platelets at perhaps 50\% the level of actinin-1 [16]. While these isoforms are similar in terms of actin binding properties, they differ in their regulation by phosphorylation, have some isoform specific interactions and can have different localization patterns in cells. The roles of actinin-4, as well as the importance of smaller quantities of $\mathrm{Ca}^{++}$insensitive actinin- 2 in platelets merit further investigation.

It would also be nice to see some of our knowledge on actinin biology translated into useful therapeutics. O'Brien et al. (2019) reported a step in that direction with the description of an actinin peptide that can potentially modulate platelet activation [97]. In their search for short linear motifs (SLiMs) as potential peptide therapeutics, they identified an actinin-1 peptide that binds vinculin. When fused to a cell penetrating TAT sequence, this peptide was capable of modulating platelet aggregation, presumably by disrupting the interaction of vinculin with actinin. It will be interesting to see if further progress can be made in this direction.

Assuming that increased association with actin filaments is the core mechanism underlying actinin-1-linked CMTP, then key questions are: exactly how, and at what stage(s), does this defect disrupt platelet production? Whatever process is affected must be exquisitely sensitive to the crosslinking activity of actinin-1, since no effects of these actinin1 mutations have been observed in other cell or tissue types. Given the relative rarity of the disorder, the development of a transgenic mouse model in which one or more of the human CMTP-causing mutations is incorporated into the mouse Actn1 gene, hopefully recapitulating the essential features of the human condition, will be of great assistance in this regard. Such a model would allow one to examine in detail the earlier steps in megakaryocyte development and maturation that are not readily accessible in patients. 
Funding: Recent research in our laboratories on platelets and actinins has been supported by a Translational Research Access Programme (TRAP) grant from the College of Medicine and Health, University College Cork and a Government of Ireland Postgraduate Scholarship from the Irish Research Council (Project ID: GOIPG/2017/952).

Institutional Review Board Statement: Not applicable.

Informed Consent Statement: Not applicable.

Data Availability Statement: Not applicable.

Conflicts of Interest: The authors declare no conflict of interest.

\section{References}

1. Cines, D.B.; Bussel, J.B.; McMillan, R.B.; Zehnder, J.L. Congenital and acquired thrombocytopenia. Hematology 2004, $2004,390-406$. [CrossRef]

2. Terrell, D.R.; Beebe, L.A.; George, J.N.; Vesely, S.K.; Mold, J.W. Referral of patients with thrombocytopenia from primary care clinicians to hematologists. Blood 2009, 113, 4126-4127. [CrossRef]

3. Sorrentino, S.; Studt, J.D.; Medalia, O.; Tanuj Sapra, K. Roll, adhere, spread and contract: Structural mechanics of platelet function. Eur. J. Cell Biol. 2015, 94, 129-138. [CrossRef] [PubMed]

4. Westbury, S.K.; Shoemark, D.K.; Mumford, A.D. ACTN1 variants associated with thrombocytopenia. Platelets 2017, 28, 625-627. [CrossRef] [PubMed]

5. Nurden, A.T.; Nurden, P. Inherited disorders of platelet function: Selected updates. J. Thromb. Haemost. 2015, 13, S2-S9. [CrossRef] [PubMed]

6. Blanchard, A.; Ohanian, V.; Critchley, D. The structure and function of alpha-actinin. J. Muscle Res. Cell Motil. 1989, 10, 280-289. [CrossRef] [PubMed]

7. Virel, A.; Backman, L. Molecular evolution and structure of $\alpha$-actinin. Mol. Biol. Evol. 2004, 21, 1024-1031. [CrossRef]

8. Otey, C.A.; Carpen, O. $\alpha$-Actinin Revisited: A Fresh Look at an Old Player. Cell Motil. Cytoskelet. 2004, 111, 104-111. [CrossRef]

9. Ribeiro, E.D.A., Jr.; Pinotsis, N.; Ghisleni, A.; Salmazo, A.; Konarev, P.V.; Kostan, J.; Sjöblom, B.; Schreiner, C.; Polyansky, A.A.; Gkougkoulia, E.A.; et al. The structure and regulation of human muscle $\alpha$-actinin. Cell 2014, 159, 1447-1460. [CrossRef]

10. Young, P.; Gautel, M. The interaction of titin and alpha-actinin is controlled by a phospholipid-regulated intramolecular pseudoligand mechanism. EMBO J. 2000, 19, 6331-6340. [CrossRef]

11. Prebil, S.D.; Slapšak, U.; Pavšič, M.; Ilc, G.; Puž, V.; Ribeiro, E.D.A.; Anrather, D.; Hartl, M.; Backman, L.; Plavec, J.; et al. Structure and calcium-binding studies of calmodulin-like domain of human non-muscle $\alpha$-actinin-1. Sci. Rep. 2016, 6, 27383. [CrossRef] [PubMed]

12. Golji, J.; Collins, R.; Mofrad, M.R.K. Molecular mechanics of the $\alpha$-actinin rod domain: Bending, torsional, and extensional behavior. PLoS Comput. Biol. 2009, 5, e1000389. [CrossRef]

13. Foley, K.S.; Young, P.W. An analysis of splicing, actin-binding properties, heterodimerization and molecular interactions of the non-muscle $\alpha$-actinins. Biochem. J. 2013, 452, 477-488. [CrossRef] [PubMed]

14. Rosenberg, S.; Stracher, A.; Burridge, K. Isolation and characterization of a calcium-sensitive alpha-actinin-like protein from human platelet cytoskeletons. J. Biol. Chem. 1981, 256, 12986-12991. [CrossRef]

15. Izaguirre, G.; Aguirre, L.; Hu, Y.P.; Lee, H.Y.; Schlaepfer, D.D.; Aneskievich, B.J.; Haimovich, B. The cytoskeletal/non-muscle isoform of $\alpha$-actinin is phosphorylated on its actin-binding domain by the focal adhesion kinase. J. Biol. Chem. 2001, 276, 28676-28685. [CrossRef] [PubMed]

16. Burkhart, J.M.; Vaudel, M.; Gambaryan, S.; Radau, S.; Walter, U.; Martens, L.; Geiger, J.; Sickmann, A.; Zahedi, R.P. The first comprehensive and quantitative analysis of human platelet protein composition allows the comparative analysis of structural and functional pathways. Blood J. Am. Soc. Hematol. 2012, 120, e73-e82. [CrossRef]

17. Sorrentino, S.; Studt, J.; Bokstad, M.; Medalia, O.; Sapra, K.T. Toward correlating structure and mechanics of platelets. Cell Adh. Migr. 2016, 10, 568-575. [CrossRef] [PubMed]

18. Cahill, M.R.; Newland, A.C. Platelet activation in coronary artery disease. Br. J. Biomed. Sci. 1993, 50, $221-234$.

19. Rubenstein, D.A.; Yin, W. Platelet-activation mechanisms and vascular remodeling. Compr. Physiol. 2018, 8, 1117-1156.

20. Schollmeyer, J.V.; Rao, G.H.R.; White, J.G. An actin-binding protein in human platelets. Interactions with $\alpha$-actinin on gelatin of actin and the influence of cytochalasin B. Am. J. Pathol. 1978, 93, 433-446.

21. Debus, E.; Weber, K.; Osborn, M. The cytoskeleton of blood platelets viewed by immunofluorescence microscopy. Eur. J. Cell Biol. 1981, 24, 45-52. [PubMed]

22. Gonnella, P.A.; Nachmias, V.T. Platelet activation and microfilament bundling. J. Cell Biol. 1981, 89, 146-151. [CrossRef]

23. Landon, F.; Gache, Y.; Touitou, H.; Olomucki, A. Properties of two isoforms of human blood platelet alpha-actinin. Eur. J. Biochem. 1985, 153, 231-237. [CrossRef] [PubMed]

24. Rotman, A. Receptor and non receptor-mediated activation of blood platelets. Effect on membrane-cytoskeleton interaction. Biochem. Biophys. Res. Commun. 1984, 120, 898-906. [CrossRef] 
25. Pho, D.B.; Desbruyeres, E.; Der Terrossian, E.; Olomucki, A. Cytoskeletons of ADP- and thrombin-stimulated platelets blood. FEBS 1986, 202, 117-121. [CrossRef]

26. May, J.A.; Glenn, J.R.; Spangenberg, P.; Heptinstall, S. The composition of the platelet cytoskeleton following activation by ADP: Effects of various agents that modulate platelet function. Platelets 1996, 7, 159-168. [CrossRef]

27. Jockusch, B.M.; Burger, M.M.; Da Prada, M.; Richards, J.G.; Chapponier, C.; Gabbiani, G. $\alpha$-Actinin attached to membranes of secretory vesicles. Nature 1977, 270, 628-629. [CrossRef] [PubMed]

28. Burn, P.; Rotman, A.; Meyer, R.K.; Burger, M.M. Diacylglycerol in large $\alpha$-actinin/actin complexes and in the cytoskeleton of activated platelets. Nature 1985, 314, 469-472. [CrossRef] [PubMed]

29. Billett, H.H.; Jenkins, C.S.; Maimon, J.J.; Spaet, T.H.; Puszkin, E.G. Platelet cytoskeleton: Immunofluorescence studies on ADP and collagen-activated platelets. J. Lab. Clin. Med. 1984, 103, 534-548. [PubMed]

30. Takubo, T.; Hino, M.; Suzuki, K.; Tatsumi, N. Relative distribution of myosin, actin, and alpha-actinin in adherent monocytes. Eur. J. Histochem. 1999, 43, 71-77. [PubMed]

31. Poulter, N.S.; Pollitt, A.Y.; Davies, A.; Malinova, D.; Nash, G.B.; Hannon, M.J.; Pikramenou, Z.; Rappoport, J.Z.; Hartwig, J.H.; Owen, D.M.; et al. Platelet actin nodules are podosome-like structures dependent on Wiskott-Aldrich syndrome protein and ARP2/3 complex. Nat. Commun. 2015, 6, 7254. [CrossRef] [PubMed]

32. Gremmel, T.; Frelinger, A.L., III; Michelson, A.D. Platelet physiology. In Seminars in Thrombosis and Hemostasis; Thieme Medical Publishers: New York, NY, USA, 2016.

33. Otey, C.A.; Pavalko, F.M.; Burridge, K. An interaction between $\alpha$-actinin land the $\beta 1$ integrin subunit in vitro. J. Cell Biol. 1990, 111, 721-729. [CrossRef]

34. Lin, S.Y.; Raval, S.; Zhang, Z.; Deverill, M.; Siminovitch, K.A.; Branch, D.R.; Haimovich, B. The protein-tyrosine phosphatase SHP-1 regulates the phosphorylation of $\alpha$-actinin. J. Biol. Chem. 2004, 279, 25755-25764. [CrossRef]

35. Sprague, C.R.; Fraley, T.S.; Hyo, S.J.; Lal, S.; Greenwood, J.A. Phosphoinositide binding to the substrate regulates susceptibility to proteolysis by calpain. J. Biol. Chem. 2008, 283, 9217-9223. [CrossRef] [PubMed]

36. Corgan, A.M.; Singleton, C.; Santoso, C.B.; Greenwood, J.A. Phosphoinositides differentially regulate $\alpha$-actinin flexibility and function. Biochem. J. 2004, 378, 1067-1072. [CrossRef] [PubMed]

37. Fraley, T.S.; Pereira, C.B.; Tran, T.C.; Singleton, C.A.; Greenwood, J.A. Phosphoinositide binding regulates $\alpha$-actinin dynamics: Mechanism for modulating cytoskeletal remodeling. J. Biol. Chem. 2004, 280, 15479-15482. [CrossRef]

38. Tadokoro, S.; Nakazawa, T.; Kamae, T.; Kiyomizu, K.; Kashiwagi, H.; Honda, S.; Kanakura, Y.; Tomiyama, Y. Apotential role for $\alpha$-actinin in inside-out $\alpha \mathrm{IIb} \beta 3$ signaling. Blood 2011, 117, 250-258. [CrossRef] [PubMed]

39. Roca-Cusachs, P.; Del Rio, A.; Puklin-Faucher, E.; Gauthier, N.C.; Biais, N.; Sheetz, M.P. Integrin-dependent force transmission to the extracellular matrix by $\alpha$-actinin triggers adhesion maturation. Proc. Natl. Acad. Sci. USA 2013, 110, E1361-E1370. [CrossRef]

40. Shams, H.; Mofrad, M.R.K. $\alpha$-Actinin Induces a Kink in the Transmembrane Domain of $\beta 3$-Integrin and Impairs Activation via Talin. Biophys. J. 2017, 113, 948-956. [CrossRef]

41. Simon, D.I.; Chen, Z.; Xu, H.; Li, C.Q.; Dong, J.-f.; McIntire, L.V.; Ballantyne, C.M.; Zhang, L.; Furman, M.I.; Berndt, M.C.; et al. Platelet glycoprotein $\mathrm{Ib} \alpha$ is a counterreceptor for the leukocyte integrin Mac-1 (CD11b/CD18). J. Exp. Med. 2000, 192, 193-204. [CrossRef]

42. Boeckelmann, D.; Hengartner, H.; Greinacher, A.; Nowak-Göttl, U.; Sachs, U.; Peter, K.; Sandrock-Lang, K.; Zieger, B. Patients with Bernard-Soulier syndrome and different severity of the bleeding phenotype. Blood Cells. Mol. Dis. 2017, 67, 69-74. [CrossRef]

43. Reséndiz, J.C.; Feng, S.; Ji, G.; Kroll, M.H. von Willebrand factor binding to platelet glycoprotein Ib-IX-V stimulates the assembly of an alpha-actinin-based signaling complex. J. Thromb. Haemost. 2004, 2, 161-169. [CrossRef]

44. Feng, S.; Reséndiz, J.C.; Christodoulides, N.; Lu, X.; Arboleda, D.; Berndt, M.C.; Kroll, M.H. Pathological shear stress stimulates the tyrosine phosphorylation of $\alpha$-actinin associated with the glycoprotein Ib-IX complex. Biochemistry 2002, 41, 1100-1108. [CrossRef]

45. Bauer, K.; Kratzer, M.; Otte, M.; de Quintara, K.L.; Hagmann, J.; Arnold, G.J.; Eckerskorn, C.; Lottspeich, F.; Siess, W. Human CLP36, a PDZ-domain and LIM-domain protein, binds to $\alpha$-actinin- 1 and associates with actin filaments and stress fibers in activated platelets and endothelial cells. Blood 2000, 96, 4236-4245. [CrossRef]

46. Bozulic, L.; Malik, M.; Powell, D.; Nanez, A.; Link, A.; Ramos, D. Plasma membrane Ca2+-ATPaseassociates withCLP36, $\alpha$-actinin andactin in human platelets. Thromb. Haemost. 2007, 97, 587-597. [CrossRef]

47. Shao, H.; Wu, C.; Wells, A. Phosphorylation of $\alpha$-actinin 4 upon epidermal growth factor exposure regulates its interaction with actin. J. Biol. Chem. 2010, 285, 2591-2600. [CrossRef]

48. Travers, T.; Shao, H.; Wells, A.; Camacho, C.J. Modeling the assembly of the multiple domains of $\alpha$-actinin- 4 and its role in actin cross-linking. Biophys. J. 2013, 104, 705-715. [CrossRef] [PubMed]

49. Travers, T.; Shao, H.; Joughin, B.A.; Lauffenburger, D.A.; Wells, A.; Camacho, C.J. Tandem phosphorylation within an intrinsically disordered region regulates ACTN4 function. Sci. Signal. 2015, 8, ra51. [CrossRef]

50. Shao, H.; Wang, A.; Lauffenburger, D.; Wells, A. Tyro3-mediated phosphorylation of ACTN4 at tyrosines is FAK-dependent and decreases susceptibility to cleavage by m-Calpain. Int. J. Biochem. Cell Biol. 2018, 95, 73-84. [CrossRef] [PubMed]

51. Shao, H.; Travers, T.; Camacho, C.; Wells, A. The carboxyl tail of alpha-actinin-4 regulates its susceptibility to m-calpain and thus functions in cell migration and spreading. Int. J. Biochem. Cell Biol. 2013, 45, 1051-1063. [CrossRef] [PubMed]

52. Foley, K.S.; Young, P.W. The non-muscle functions of actinins: An update. Biochem. J. 2014, 459, 1-13. [CrossRef] 
53. Redondo, P.C.; Harper, A.G.S.; Harper, M.T.; Brownlow, S.L.; Rosado, J.A.; Sage, S.O. hTRPC1-associated $\alpha$-actinin, and not hTRPC1 itself, is tyrosine phosphorylated during human platelet activation. J. Thromb. Haemost. 2007, 5, 2476-2483. [CrossRef] [PubMed]

54. Marcondes, S.; Cardoso, M.H.M.; Morganti, R.P.; Thomazzi, S.; Lilla, S.; Murad, F.; De Nucci, G.; Antunes, E. Cyclic GMPindependent mechanisms contribute to the inhibition of platelet adhesion by nitric oxide donor: A role for -actinin nitration. Proc. Natl. Acad. Sci. USA 2006, 103, 3434-3439. [CrossRef] [PubMed]

55. Poulter, N.S.; Thomas, S.G. Cytoskeletal regulation of platelet formation: Coordination of F-actin and microtubules. Int. J. Biochem. Cell Biol. 2015, 66, 69-74. [CrossRef]

56. Machlus, K.R.; Thon, J.N.; Italiano, J.E. Interpreting the developmental dance of the megakaryocyte: A review of the cellular and molecular processes mediating platelet formation. Br. J. Haematol. 2014, 165, 227-236. [CrossRef] [PubMed]

57. Mukhina, S.; li Wang, Y.; Murata-Hori, M. $\alpha$-actinin is required for tightly regulated remodeling of the actin cortical network during cytokinesis. Dev. Cell 2007, 13, 554-565. [CrossRef]

58. Elagib, K.E.; Rubinstein, J.D.; Delehanty, L.L.; Ngoh, V.S.; Greer, P.A.; Li, S.; Lee, J.K.; Li, Z.; Orkin, S.H.; Mihaylov, I.S.; et al Calpain 2 activation of P-TEFb drives megakaryocyte morphogenesis and is disrupted by leukemogenic GATA1 mutation. Dev. Cell 2013, 607-620. [CrossRef]

59. Raslova, H.; Kauffmann, A.; Sekkaï, D.; Ripoche, H.; Larbret, F.; Robert, T.; Le Roux, D.T.; Kroemer, G.; Debili, N.; Dessen, P.; et al. Interrelation between polyploidization and megakaryocyte differentiation: A gene profiling approach. Blood 2007, 109, 3225-3234. [CrossRef]

60. Machlus, K.R.; Italiano, J.E. The incredible journey: From megakaryocyte development to platelet formation. J. Cell Biol. 2013, 201, 785-796. [CrossRef]

61. Bender, M.; Thon, J.N.; Ehrlicher, A.J.; Wu, S.; Mazutis, L.; Deschmann, E. Microtubule sliding drives proplatelet elongation and is dependent on cytoplasmic dynein. Blood 2015, 125, 860-868. [CrossRef]

62. Italiano, J.E., Jr.; Lecine, P.; Shivdasani, R.A.; Hartwig, J.H. Blood platelets are assembled principally at the ends of proplatelet processes produced by differentiated megakaryocytes. J. Cell Biol 1999, 147, 1299-1312. [CrossRef] [PubMed]

63. Kunishima, S.; Okuno, Y.; Yoshida, K.; Shiraishi, Y.; Sanada, M.; Muramatsu, H.; Chiba, K.; Tanaka, H.; Miyazaki, K.; Sakai, M.; et al. ACTN1 mutations cause congenital macrothrombocytopenia. Am. J. Hum. Genet. 2013, 92, 431-438. [CrossRef]

64. Hauschner, H.; Mor-Cohen, R.; Messineo, S.; Mansour, W.; Seligsohn, U.; Savoia, A.; Rosenberg, N. Abnormal cytoplasmic extensions associated with active $\alpha \mathrm{Ilb} \beta 3$ are probably the cause for macrothrombocytopenia in Glanzmann thrombasthenia-like syndrome. Blood Coagul. Fibrinolysis 2015, 26, 302-308. [CrossRef] [PubMed]

65. Kunishima, S.; Tomiyama, Y.; Saito, H. Heterozygous ITGA2B R995W mutation inducing constitutive activation of the $\alpha$ IIb $\beta 3$ receptor affects proplatelet formation and causes congenital macrothrombocytopenia. Blood 2011, 117, 5479-5484. [CrossRef]

66. Rosa, J.P.; Raslova, H.; Bryckaert, M. Filamin A: Key actor in platelet biology. Blood 2019, 134, 1279-1288. [CrossRef]

67. Eckly, A.; Scandola, C.; Oprescu, A.; Michel, D.; Rinckel, J.-Y.; Proamer, F.; Hoffmann, D.; Receveur, N.; Léon, C.; Bear, J.E.; et al. Megakaryocytes use in vivo podosome-like structures working collectively to penetrate the endothelial barrier of bone marrow sinusoids. J. Thromb. Haemost. 2020, 18, 2987-3001. [CrossRef]

68. Schachtner, H.; Calaminus, S.D.J.; Sinclair, A.; Monypenny, J.; Blundell, M.P.; Leon, C.; Holyoake, T.L.; Thrasher, A.J.; Michie, A.M.; Machesky, L.M.; et al. Megakaryocytes assemble podosomes that degrade matrix and protrude through basement membrane. Blood 2013, 121, 2542-2552. [CrossRef] [PubMed]

69. Cox, S.; Rosten, E.; Monypenny, J.; Jovanovic-Talisman, T.; Burnette, D.T.; Lippincott-Schwartz, J.; Jones, G.E.; Heintzmann, R. Bayesian localisation microscopy reveals nanoscale podosome dynamics. Nat. Methods 2012, 9, 195-200. [CrossRef]

70. van den Dries, K.; Schwartz, S.L.; Byars, J.; Meddens, M.B.M.; Bolomini-Vittori, M.; Lidke, D.S.; Figdor, C.G.; Lidke, K.A.; Cambi, A. Dual-color superresolution microscopy reveals nanoscale organization of mechanosensory podosomes. Mol. Biol. Cell 2013, 24, 2112-2123. [CrossRef]

71. van den Dries, K.; Nahidiazar, L.; Slotman, J.A.; Meddens, M.B.M.; Pandzic, E.; Joosten, B.; Ansems, M.; Schouwstra, J.; Meijer, A.; Steem, R.; et al. Modular actin nano-architecture enables podosome protrusion and mechanosensing. Nat. Commun. 2019, 10, 5171. [CrossRef]

72. Massaad, M.J.; Ramesh, N.; Geha, R.S. Wiskott-Aldrich syndrome: A comprehensive review. Ann. N. Y. Acad. Sci. 2013, 1285, 26-43. [CrossRef]

73. Sabri, S.; Foudi, A.; Boukour, S.; Franc, B.; Charrier, S.; Jandrot-Perrus, M.; Farndale, R.W.; Jalil, A.; Blundell, M.P.; Cramer, E.M.; et al. Deficiency in the Wiskott-Aldrich protein induces premature proplatelet formation and platelet production in the bone marrow compartment. Blood 2006, 108, 134-140. [CrossRef]

74. Becker, I.C.; Scheller, I.; Wackerbarth, L.M.; Beck, S.; Heib, T.; Aurbach, K.; Manukjan, G.; Gross, C.; Spindler, M.; Nagy, Z.; et al. Actin/microtubule crosstalk during platelet biogenesis in mice is critically regulated by Twinfilin1 and Cofilin1. Blood Adv. 2020, 4, 2124-2134. [CrossRef]

75. Thon, J.N.; Montalvo, A.; Patel-Hett, S.; Devine, M.T.; Richardson, J.L.; Ehrlicher, A.; Larson, M.K.; Hoffmeister, K.; Hartwig, J.H.; Italiano, J.E., Jr.; et al. Cytoskeletal mechanics of proplatelet maturation and platelet release. J. Cell Biol. 2010, 191, 861-874. [CrossRef]

76. Thon, J.N.; Macleod, H.; Begonja, A.J.; Zhu, J.; Lee, C.-K.; Mogilner, A.; Hartwig, J.H.; Italiano, J.E., Jr. Microtubule and cortical forces determine platelet size during vascular platelet production. Nat. Commun. 2012, 3, 852. [CrossRef] 
77. Spinler, K.R.; Shin, J.-W.; Lambert, M.P.; Discher, D.E. Myosin-II repression favors pre/proplatelets but shear activation generates platelets and fails in macrothrombocytopenia. Blood 2015, 125, 525. [CrossRef]

78. Schiffhauer, E.S.; Luo, T.; Mohan, K.; Srivastava, K.; Qian, X.; Griffis, E.R.; Iglesias, P.A.; Robinson, D.N. Mechanoaccumulative elements of the mammalian actin cytoskeleton. Curr. Biol. 2016, 26, 1473-1479. [CrossRef]

79. Thomas, D.G.; Robinson, D.N. The fifth sense: Mechanosensory regulation of alpha-actinin- 4 and its relevance for cancer metastasis. Semin. Cell Dev. Biol. 2017, 71, 68-74. [CrossRef] [PubMed]

80. Meacci, G.; Wolfenson, H.; Liu, S.; Stachowiak, M.R.; Iskratsch, T.; Mathur, A.; Ghassemi, S.; Gauthier, N.; Tabdanov, E.; Lohner, J.; et al. $\alpha$-Actinin links extracellular matrix rigidity-sensing contractile units with periodic cell-edge retractions. Mol. Biol. Cell 2016, 27, 3471-3479. [CrossRef] [PubMed]

81. Weins, A.; Schlondorff, J.S.; Nakamura, F.; Denker, B.M.; Hartwig, J.H.; Stossel, T.P.; Pollak, M.R. Disease-associated mutant $\alpha$-actinin-4 reveals a mechanism for regulating its F-actin-binding affinity. Proc. Natl. Acad. Sci. USA 2007, 104, 16080-16085. [CrossRef] [PubMed]

82. Murphy, A.C.H.; Young, P.W. The actinin family of actin cross-linking proteins-A genetic perspective. Cell Biosci. $2015,5,49$. [CrossRef]

83. Kaplan, J.M.; Kim, S.H.; North, K.N.; Rennke, H.; Correia, L.A.; Tong, H.-Q.; Mathis, B.J.; Rodríguez-Pérez, J.-C.; Allen, P.G.; Beggs, A.H.; et al. Mutations in ACTN4, encoding $\alpha$-actinin-4, cause familial focal segmental glomerulosclerosis. Nat. Genet. 2000, 24, 251-256. [CrossRef]

84. Kos, C.H.; Le, T.C.; Sinha, S.; Henderson, J.M.; Kim, S.H.; Sugimoto, H.; Kalluri, R.; Gerszten, R.E.; Pollak, M.R. Mice deficient in $\alpha$-actinin-4 have severe glomerular disease. J. Clin. Investig. 2003, 111, 1683-1690. [CrossRef] [PubMed]

85. Guéguen, P.; Rouault, K.; Chen, J.-M.; Raguénès, O.; Fichou, Y.; Hardy, E.; Gobin, E.; Pan-petesch, B.; Kerbiriou, M.; Trouvé, P.; et al. A missense mutation in the alpha-actinin 1 gene (ACTN1) is the cause of autosomal dominant macrothrombocytopenia in a large French family. PLoS ONE 2013, 8, e74728. [CrossRef]

86. Faleschini, M.; Melazzini, F.; Marconi, C.; Giangregorio, T.; Pippucci, T.; Cigalini, E.; Pecci, A.; Bottega, R.; Ramneghi, U.; Siitonen, T.; et al. ACTN1 mutations lead to a benign form of platelet macrocytosis not always associated with thrombocytopenia. Br. J. Haematol. 2018, 183, 276-288. [CrossRef]

87. Kanhai, D.; Mulder, R.; Ploos van Amstel, H.K.; Schutgens, R.; Lukens, M.; Tamminga, R.Y. Familial macrothrombocytopenia due to a double mutation in cis in the alpha-actinin 1 gene (ACTN1), previously considered to be chronic immune thrombocytopenic purpura. Pediatric Blood Cancer 2018, 65, e27418. [CrossRef] [PubMed]

88. Vincenot, A.; Saultier, P.; Kunishima, S.; Poggi, M.; Hurtaud-Roux, M.-F.; Roussel, A.; ACTN1 study coinvestigators; Schlegel, N.; Alessi, M.-C. Novel ACTN1 variants in cases of thrombocytopenia. Hum. Mutat. 2019, 40, 2258-2269. [CrossRef]

89. Andres, O.; König, E.M.; Klopocki, E.; Schulze, H. Use of targeted high-throughput sequencing for genetic classification of patients with bleeding diathesis and suspected platelet disorder. Hämostaseologie 2019, 39, S1-S92.

90. Luo, F.M.; Fan, L.L.; Sheng, Y.; Dong, Y.; Liu, L. Case report: Exome sequencing identified a novel frameshift mutation of $\alpha$-actin 1 in a chinese family with macrothrombocytopenia and mild bleeding. Front. Pediatrics 2021, 9, 679279. [CrossRef]

91. Bottega, R.; Marconi, C.; Faleschini, M.; Baj, G.; Cagioni, C.; Pecci, A.; Pippucci, T.; Ramenghi, U.; Pardini, S.; Ngu, L.; et al. ACTN1-related thrombocytopenia: Identification of novel families for phenotypic characterization. Blood 2015, 125, 869-872. [CrossRef]

92. Yasutomi, M.; Kunishima, S.; Okazaki, S.; Tanizawa, A.; Tsuchida, S.; Ohshima, Y. ACTN1 rod domain mutation associated with congenital macrothrombocytopenia. Ann. Hematol. 2016, 95, 141-144. [CrossRef]

93. Murphy, A.C.; Lindsay, A.J.; McCaffrey, M.W.; Djinović-Carugo, K.; Young, P.W. Congenital macrothrombocytopenia-linked mutations in the actin-binding domain of $\alpha$-actinin-1 enhance F-actin association. FEBS Lett. 2016, 590, 685-695. [CrossRef] [PubMed]

94. O'Sullivan, L.R.; Ajaykumar, A.P.; Dembicka, K.M.; Murphy, A.; Grennan, E.P.; Young, P.W. Investigation of calmodulin-like and rod domain mutations suggests common molecular mechanism for $\alpha$-actinin-1-linked congenital macrothrombocytopenia. FEBS Lett. 2020, 594, 161-174. [CrossRef] [PubMed]

95. Schick, U.M.; Jain, D.; Hodonsky, C.J.; Morrison, J.V.; Davis, J.P.; Brown, L.; Sofer, T.; Conomos, M.P.; Schurmann, C.; McHugh, C.P.; et al. Genome-wide association study of platelet count identifies ancestry-specific loci in Hispanic/Latino Americans. Am. J. Hum. Genet. 2016, 98, 229-242. [CrossRef] [PubMed]

96. Astle, W.J.; Elding, H.; Jiang, T.; Allen, D.; Ruklisa, D.; Mann, A.L.; Mead, D.; Bouman, H.; Riveros-Mckay, F.; Kostadima, M.A.; et al. The allelic landscape of human blood cell trait variation and links to common complex disease. Cell 2016, 167, 1415-1429. [CrossRef]

97. O’Brien, K.T.; Golla, K.; Kranjc, T.; O’Donovan, D.; Allen, S.; Maguire, P.; Simpson, J.C.; O'Connel, D.; Moran, N.; Shields, D.C. Computational and experimental analysis of bioactive peptide linear motifs in the integrin adhesome. PLoS ONE 2019, 14, e021033. [CrossRef] [PubMed] 